\title{
ANALISIS PENGARUH KEPEMIMPINAN, MOTIVASI DAN STRES KERJA TERHADAP KINERJA KARYAWAN CV. DIAN PRIMA KEBUMEN
}

\section{Parmin}

\begin{abstract}
ABSTRAK
Penelitian ini dilakukan di CV. Dian Prima Kebumen. Tujuan penelitian ini untuk mengetahui pengaruh kepemimpinan, motivasi dan stres kerja terhadap kinerja karyawan. Populasi penelitian adalah seluruh karyawan CV. Dian Prima Kebumen yang berjumlah 41 orang. Penelitian ini mengggunakan metode analisis deskriptif dan statistika dengan bantuan program SPSS 18.00.Dalam metode statistika, dilakukan uji validitas, reliabilitas, pengujian asumsi klasik, analisis regresi berganda, uji hipotesis dengan uji $t$ maupun uji $F$ dan koefisien determinasi/r square.

Pengujian hipotesis menunjukkan, hasil uji t bahwa variable kepemimpinan, motivasi yang berpengaruh signifikan secara parsial/sendiri-sendiri terhadap kinerja karyawan semua variabel berpengaruh signifikan terhadap kinerja karyawan, kecuali variabel stres kerja. Sedangkan hasil uji $F$ menunjukkan nilai yang signifikan sehingga diartikan bahwasecara bersama-sama variabel kepemimpinan, motivasi dan stres kerja memiliki pengaruh yang signifikan terhadap kinerja karyawan CV. Dian Prima Kebumen.
\end{abstract}

Kata Kunci : Kepemimpinan, Motivasi, stres kerjs dan Kinerja Karyawan

\section{PENDAHULUAN}

\section{Latar Belakang Penelitian}

Kinerja karyawan merupakan hasil kerja yang dicapai seseorang dalam melaksanakan tugas-tugas yang dibebankan kepadanya. Kinerja karyawan meliputi kualitas dan kuantitas output serta keandalan dalam bekerja. Karyawan dapat bekerja dengan baik bila memiliki kinerja yang tinggi sehingga dapat menghasilkan kerja yang baik pula. Dengan adanya kinerja yang tinggi yang dimiliki oleh karyawan, diharapkan tujuan organisasi dapat tercapai. Sebaliknya tujuan organisasi sulit atau bahkan tidak dapat tercapai bila karyawannya bekerja tidak memiliki kinerja yang baik, sehingga tidak dapat menghasilkan kinerja yang baik pula.

Motivasi kerja karyawan perlu dicermati secara sistematis perkembangannya dan juga memerlukan perhatian dari atasan perusahaan itu sendiri, sehingga dapat meningkatkan perilaku kerja karyawan. Walaupun kita telah memiliki karyawan dengan baik berdasarkan pada kemampuannya yang telah dilengkapi dengan latihan yang relevan, akan tetapi motivasi juga harus dipertimbangkan agar hasil kerja lebih optimal. Untuk mendukung motivasi kerja karyawan dengan motivasi maka karyawan distributor CV. Dian Prima Kebumen harus mampu bekerja secara optimal. Dengan dasar ini maka perusahan hendaknya berupaya secara maksimal untuk senantiasa menjaga dan meningkatkan motivasi kerja bagi karyawanya.

Komponen yang dapat meningkatkan motivasi antara lain terpenuhinya kebutuhan, keinginan, perilaku, tujuantujuan, imbalan-imbalan, serta umpan balik perusahaan terhadap karyawan. Dalam hal ini perusahaan berupaya maksimal untuk menciptakan situasi yang memotivasi yaitu dengan motif-motif seorang individu, 
diarahkan kearah pencapaiaan tujuan.

Stres dapat terjadi dalam setiap jajaran yang ada dalam suatu perusahaan baik staf maupun pimpinan. Stres kerja dapat meningkatkan atau menurunkan kinerja kerja, tantangan kerja hilang dan kinerja kerja cenderung menurun. Namun, dengan bertambahnya stres kecenderungan meningkatnya kinerja bertambah karena stresmenolong orang mengeluarkan mengeluarkan potensi untuk memenuhi persyaratan kerja. Tapi jika stres terlalu tinggi maka prestasi kerja akan menurun dan individu akan kehilangan kemampuan untuk mengatasinya. Akibatnya adalah stres kerja sampai ke titik yang paling tinggi dan prestasi kerjanya akan menjadi nol.

Adanya tuntutan kerja yang professional itu secara otomatis menimbulkan stress kerja bagi karyawan. Stres pada pekerjaan yang ditimbulkan oleh kondisi- kondisi dilingkungan kerja, kondisi- kondisi lain diluar lingkungan kerja, maupun dari diri pribadi seseorang. Lingkungan kerja yang dapat menimbulkan stres dapat merupakan lingkungan fisik maupun dalam perusahaan.

\section{Rumusan Masalah}

Beberapa masalah yang dapat diambil sebagai kesimpulan dari variabel judul diatas adalah :

1. Apakah ada pengaruh kepemimpinan terhadap kinerja karyawan CV. Dian Prima Kebumen?

2. Apakah ada pengaruh motivasi terhadap kinerja karyawan CV. Dian Prima Kebumen?

3. Apakah ada pengaruh stres kerja terhadap kinerja karyawan CV. Dian Prima Kebumen?

4. Apakah ada pengaruh secara simultan antara kepemimpinan, motivasi, stres kerja terhadap kinerja karyawan CV. Dian Prima Kebumen?

\section{Tujuan Penelitian}

Sesuai dengan permasalahan yang dirumuskan diatas, maka penelitian ini mempunyai tujuan sebagi berikut : Untuk menganalisis pengaruh kepemimpinan terhadap kinerja karyawan CV. Dian Prima Kebumen. Untuk menganalisis pengaruh motivasi kerja terhadap kinerja karyawan CV. Dian Prima Kebumen. Untuk menganalisis pengaruh stres kerja terhadap kinerja karyawan $\mathrm{CV}$. Dian Prima Kebumen. Untuk menganalisis pengaruh secara simultan antara kepemimpinan, motivasi dan stres kerja terhadap kinerja karyawan CV. Dian Prima Kebumen.

\section{Landasan teori \\ Kinerja}

Kinerja atau performance menurut Prawirosentono dalam Suwarso (2006:26) adalah hasil kerja yang dapat dipakai oleh seseorang atau sekelompok orang dalam suatu organisasi sesuai dengan wewenang dan tanggungjawabnya masing-masing dalam rangka upaya mencapai tujuan organisasi yang bersangkutan secara legal, tidak melanggar hukum dan sesuai dengan moral maupun etika. Pengertian lain diungkapkan oleh Mangkunegoro (2004:67) yang menjelaskan bahwa kinerja adalah hasil kerja secara kualitas dan kuantitas yng dicapai oleh seorang karyawan dalam melaksanakan tugasnya sesuai dengan tanggungjawab yang diberikan kepadanya.

Kinerja tidak bersifat konstan, melainkan bersifat fluktuatif sehingga pada suatu saat bisa meningkat dan pada suatu saat bisa mengalami penurunan. Oleh karena itu kinerja dari waktu ke waktu dapat dan perlu dinilai, misalnya secara periodik setiap tahunnya atau dalam kurun waktu lain sesuai dengan kebutuhan organisasi.Kinerja setiap individu berbeda dengan individu lainnya sesuai dengan tingkat besar dan kecilnya pengetahuan, keterampilan dan motivasi yang dimiliki oleh individu tersebut. Demikian pula dengan kelompok, kinerja 
kelompok satu dengan lainnya tidak akan sama karena komposisi anggota kelompok memiliki perbedaan pemahaman tentang kinerja secara berbeda pula. Untuk memberikan kesamaan kinerja, maka organisasi harus menetapkan pengukuran yang baku dan standar agar dapat dijadikan pedoman oleh setiap karyawan. Kinerja (hasil kerja) berpengaruh positif dan signifikan terhadap kepuasan kerja karyawan.

\section{Kepemimpinan}

Malayu S.P. Hasibuan, Pemimpin adalah seseorang dengan wewenang kepemimpinannya mengarahkan bawahannya untuk mengerjakan sebagian dari pekerjaannya dalam mencapai tujuan. Robert Tanembaum, Pemimpin adalah mereka yang menggunakan wewenang formal untuk mengorganisasikan, mengarahkan, mengontrol para bawahan yang bertanggung jawab, supaya semua bagian pekerjaan dikoordinasi demi mencapai tujuan perusahaan. Menurut Maccoby, Pemimpin pertama-tama harus seorang yang mampu menumbuhkan dan mengembangkan segala yang terbaik dalam diri para bawahannya. Pemimpin yang baik untuk masa kini adalah orang yang religius, dalam artian menerima kepercayaan etnis dan moral dari berbagai agama secara kumulatif, kendatipun ia sendiri mungkin menolak ketentuan gaib dan ide ketuhanan yang berlainan. Pemimpin yang baik adalah seorang yang membantu mengembangkan orang lain, sehingga akhirnya mereka tidak lagi memerlukan pemimpinnya itu. Pemimpin adalah seseorang yang menduduki suatu posisi manajemen atau seseorang yang melakukan suatu pekerjaan memimpin.

\section{Motivasi}

Mangkunegara (2004) dan Utami (2010) mendefinisikan motivasi sebagai suatu dorongan kebutuhan dalam diri pegawai atau karyawan yang perlu dipenuhi agar pegawai tersebut dapat menyesuaikan diri terhadap lingkungannya untuk mencapai tujuan yang hendak dicapai seorang pegawai dalam bekerja. Sedangkanmenurut Robbins (2007) motivasi sebagai kesediaan karyawan untuk mengeluarkan tingkat upaya yang tinggi untuk tujuan organisasi,yang dikondisikan oleh kemampuan upaya itu untuk memenuhi beberapa kebutuhan individual. Begitu pula menurut Nimran (1997) motivasi adalah sebagai suatu keadaan dimana usaha dan kemauan keras seseorang diarahkan pada pencapaian hasilhasil tertentu.

\section{Stres Kerja}

Menurut Handoko (2011),stres adalah suatu kondisi ketegangan yang mempengaruhi emosi, proses berfikir dan kondisi seseorang, stress yang terlalu bear dapat mengancam kemampuan seseorang untuk menghadapi lingkungan. Sebagai hasilnya, pada diri karyawan berkembang berbagai macam gejala stress yang dapat menggangu kinerja kerja mereka. Gejalagejala ini dapat berhubungan dengan kesehatan fisik serta kesehatan mental.

Menurut Pandji Anoraga (2004), stres kerja adalah suatu bentuk tanggapan seseorang, baik fisik maupun mental terhadap suatu perubahan dilingkungan yang dirasakan menggagu dan mengakibatkan dirinya terancam. Ketidakmampuan untuk melawan keterbatasan inilah yang akan menimbulkan frustasi, konflik, gelisah, dan merasa bersalah yang merupakan tipe-tipe dasar stres. Stres yang dialami oleh karyawan memengaruhi kinerja dan kepuasan kerjanya. Prestasi kerja karyawan merupakan hal yang sangat penting dalam perusahaan untuk mencapai tujuannya, sehingga berbagai berbagai usaha dilakukan untuk meningkatkannya. 


\section{Penelitian Terdahulu}

Penelitian Dewi Ma'rifah (2005) yang berjudul "Analisis pengaruh budaya kerja motivasi terhadap kinerja menemukan pengaruh signifikan positif budaya organisasi dan motivasi terhadap kinerja para pekerja sosial pada Unit Pelaksana Teknis Dinas Sosial Propinsi Jawa Timur. Penelitian ini merupakan explanatory research yang bertujuan untuk mengetahui pengaruh motivasi dan budaya organisasi terhadap kinerja. Penelitian ini melibatkan 77 responden dengan menggunakan teknik random sampling.Hasil analisis data menunjukkan bahwa semua variabel berpengaruh secara signifikan baik secara parsial maupun simultan.

Peneliti Siti Nurhendar (2007) yang berjudul " Pengaruh Stres Kerja dan Semangat Kerja terhadap Kinerja Karyawan. Bagian Produksi Studi kasus pada Aneka Ulmu Semarang" dengan 201 orang sampel penelitian dan menggunakan analisis regresi berganda menghasilkan kesimpulkan bahwa variabel Stres Kerja dan Semangat Kerja berpengaruh positif dan signifikasi terhadap kinerja karyawan. Hasil analisis data menunjukkan bahwa variabel stres kerja dan semangat kerja berpengaruh secara signifikan baik secara parsial dan simultan.

\section{Kerangka Pikir}

Berdasarkan landasan teori yang telah dibahas sebelumnya yang menyangkut kepemimpian, motivasi dan stres kerja yang mempengaruhi kinerja karyawan. makadapat disusunsuatu kerangkapemikiran teoritisyangdapatdigambarkansebagaiberikut;

\section{Gambar II.1}

\section{Model Kerangka Pemikiran Teoritis}

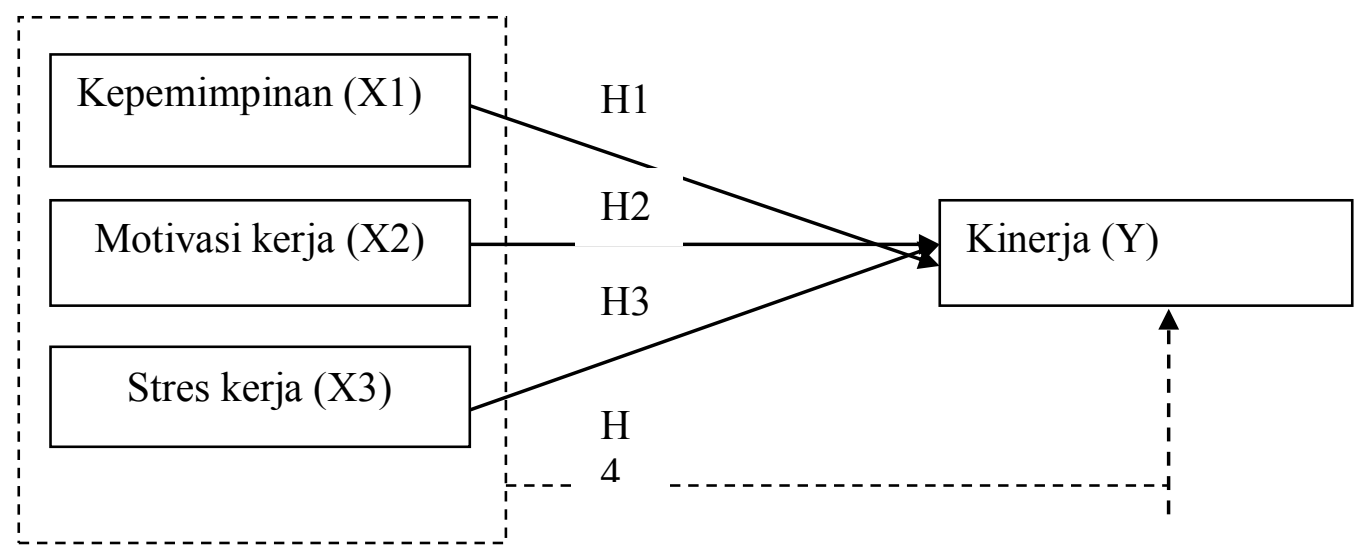

H1: Kepemimpinan berpengaruh terhadap kinerja karyawan pada CV. Dian Prima Kebumen

H2: Motivasi berpegaruh terhadap kinerja karyawan pada CV. Dian Prima Kebumen

H3: Stres kerja berpegaruh terhadap kinerja karyawan pada CV. Dian Prima Kebumen

H4: Kepemimpinan, Motivasi kerja, Stres kerja secara simultan berpengaruh signifikasi terhadap kinerja pada karyawan CV. Dian Prima Kebumen. 


\section{METODOLOGI PENELITIAN}

\section{Obyek dan Subyek Penelitian}

1. Obyek Penelitian

Obyek penelitian ini adalah kepemimpinan, motivasi dan stres kerja terhadap kinerja karyawan CV. Dian Prima Kebumen

\section{Subyek Penelitian}

Subyek penelitian ini adalah seluruh karyawan CV. Dian Prima Kebumen

\section{Variabel Penelitian dan Definisi} Operasional Variabel

Variabel Penelitian

Variabel merupakan gejala yang menjadi fokus penelitian untuk diamati, sebagai atribut dari kelompok orang atau objek yang mempunyai variasi antara satu dengan yang lainnya dalam kelompok itu, Sugiyono (2012:2). Dalam penelitian ini terdapat 2 (dua) jenis variabel yaitu:

a. Variabel bebas (independent variable) yaitu variabel yang menjadi sebab timbulnya atau berubahnya variabel terikat (dependentvariable) dengan kata lain variabel yang mempengaruhi, Sugiyono (2012:3).Dalam penelitian ini, variabel bebasnya adalah Kepemimpinan (X1), Motivasi (X2), Stres kerja (X3)

b. Variabel terikat (dependent variable) yaitu variabel yang dipengaruhi atau yang menjadi akibat karena adanya variabel bebas Sugiyono (2012:3).Dalam penelitian ini variabel terikatnya adalah kinerja karyawan (Y)

\section{Definisi Operasional Variabel}

\section{a. Kinerja (Y)}

Menurut Soedjono (2005) dalam Mariam (2009) terdapat faktor-faktor yang mempengaruhi kinerja adalah :

Tabel III-1

Indikator dan Distribusi Variabel Kinerja pada Kuesioner

\begin{tabular}{|c|l|c|c|}
\hline No & \multicolumn{1}{|c|}{ Indikator } & $\begin{array}{c}\text { Distribusi } \\
\text { butir ke }\end{array}$ & Jumlah \\
\hline 1 & Kualitas pekerjaan & 1 & 1 \\
\hline 2 & Kuantitas pekerjaan & 2 & 1 \\
\hline 3 & Ketepatan waktu & 3,4 & 2 \\
\hline 4 & Efektivitas & 5 & 1 \\
\hline 5 & Kemandirian & 6 & 1 \\
\hline 6 & Komitmen & 7,8 & 2 \\
\hline 7 & Tanggung jawab & 9,10 & 2 \\
\hline \multicolumn{2}{|c|}{ Jumlah } & 10 \\
\hline
\end{tabular}

\section{b. Kepemimpinan (X1)}

Kepemimpinan adalah adalah proses mempengaruhi atau memberi contoh oleh pemimpin kepada pengikutnya atau bawahannya dalam upaya mencapai tujuan organisasi. Adapun indikatornya adalah; 
Tabel III-2

Indikator dan Distribusi Variabel Kepemimpinan pada Kuesioner

\begin{tabular}{|l|l|r|r|}
\hline & Indikator & $\begin{array}{l}\text { Distribusi } \\
\text { butir ke }\end{array}$ & Jumlah \\
\hline & Arahan & $1,2,3$ & 3 \\
\hline & Supervisi & $4,5,6$ & 3 \\
\hline & Konsultasi & 7,8 & 2 \\
\hline & Pendelegasian Wewenang & 9.10 & 2 \\
\hline \multicolumn{2}{|c|}{ Jumlah } & 9 \\
\hline
\end{tabular}

\section{c. Motivasi (X2)}

Robbins dalam Sayuti(2006), menyebutkan bahwa pengukuran motivasi kerja dapat dilakukan dengan melihat pada beberapa aspek antara lain sebagai berikut :

'Tabel III-3

Indikator dan Distribusi Variabel Motivasi pada Kuesioner

\begin{tabular}{|c|l|c|c|}
\hline No & \multicolumn{1}{|c|}{ Indikator } & $\begin{array}{c}\text { Distribusi } \\
\text { butir ke }\end{array}$ & Jumlah \\
\hline 1 & Mempunyai sifar agresif & 1 & 1 \\
\hline 2 & $\begin{array}{l}\text { Kreatif dalam melaksanakan } \\
\text { pekerjaan }\end{array}$ & 2 & 1 \\
\hline 3 & $\begin{array}{l}\text { Mutu pekerjaan meningkat dari } \\
\text { hari ke hari }\end{array}$ & 4 & 1 \\
\hline 4 & $\begin{array}{l}\text { Mematuhi jam kerja } \\
\text { Tugas yang diselesaikan dengan } \\
\text { kemampuan }\end{array}$ & 5 & 1 \\
\hline 5 & $\begin{array}{l}\text { Inisiatif kerja tinggi dapat } \\
\text { mendorong kerja }\end{array}$ & 7 & 1 \\
\hline 6 & $\begin{array}{l}\text { Kesetiaan dan kejujuran } \\
\text { Terjalin hubungan antara karyawan } \\
\text { dengan pimpinan }\end{array}$ & 9 & 1 \\
\hline 8 & $\begin{array}{l}\text { Tercapainya tujuan perorangan dan } \\
\text { tujuan organisasi }\end{array}$ & $\begin{array}{l}\text { Menghasilkan informasi yang } \\
\text { akurat dan tepat }\end{array}$ & 10 \\
\hline 10 & \begin{tabular}{l} 
Jumlah \\
\hline
\end{tabular} & & 1 \\
\hline
\end{tabular}

\section{d. Stres kerja (X3)}

Robbin (2007;793) menyatakan stres kerja adalah kondisi dinamik yang didalamnya individu/karyawan menghadapi peluang kendala tuntutan yang terkait dengan apa yang sangat diinginkanya menyebutkan bahwa pengukuran stres kerja dapat dilakukan dengan melihat bebrapa aspek antara lain sebgai berikut : 
Tabel III-4

Indikator dan Distribusi Variabel Stres Kerja pada Kuesioner

\begin{tabular}{|l|l|r|r|}
\hline & \multicolumn{1}{|c|}{ Indikator } & $\begin{array}{l}\text { Distribusi } \\
\text { butir ke }\end{array}$ & Jumlah \\
\hline & Cepat tersinggung & 1 & 1 \\
\hline & Tidak komunikatif & 2 & 1 \\
\hline Banyak melamun & 3 & 1 \\
\hline Lelah mental & 4 & 1 \\
\hline $\begin{array}{l}\text { meningkatkan detak jantung dan } \\
\text { tekanan darah }\end{array}$ & 5 & 1 \\
\hline Mudah lelah secara fisik & 6 & 1 \\
\hline & Pusing kepala & 7 & 1 \\
\hline Problem tidur & 8 & 1 \\
\hline $\begin{array}{l}\text { Menunda atau menghindari } \\
\text { pekerjaan }\end{array}$ & 9 & 1 \\
\hline \multicolumn{2}{|l|}{ Jumlah } & & 9 \\
\hline
\end{tabular}

Instrumen atau Pengumpulan Data

Metode Pengumpulan data dilakukan dengan menggunakan kuisoner yang ditunjukan untuk memperoleh jawaban dari responden. Setelah data dari penyebaran kuisoner terkumpul, kemudian dilakukan proses skoring yaitu pemberian nilai berupa angka pada jawaban untuk memperoleh data kuantitatif yang dilakukan dalam pengujian hipotesis dengan mengunakan Skala Likert. Jawaban setiap item instrumen menggunakan Skala Likert mempunyai gradasi dari sangat positif sampai sangat negatif, yang dapat berupa kata-kata (Sugiyono, 2012:134):
a. Sangat Setuju (SS) : skor 5
b. Sejutu (S)
: skor 4
c. Ragu-ragu
: skor 3
d. Tidak Setuju
: skor 2
e. Sangat Tidak Setuju
(STS) : skor 1

Untuk keperluan analisis kuantitatif dalam penelitian ini, maka jawaban tersebut dimodifikasi sebagai berikut:
a. Sangat Setuju (SS)
: skor 4
b. Sejutu (S)
: skor 3
c. Tidak Setuju

$$
\text { : skor } 2
$$
d. Sangat Tidak Setuju
(STS) : skor 1

\section{Data dan Teknik Pengumpulan Data.}

\section{Jenis Data}

\section{Dataprimer}

Sumberdataini

diperolehlangsungdariindividuyangmenja disubjek penelitian di mana data dihasilkan dari hasil kuesioner yang disebarkan

kepadasampelyangtelahditentukansebelu mnyayaitu Karywan CV. Dian Prima Kebumen.

\section{Datasekunder}

Sumber datainidiperoleh secaratidaklangsungmelaluimediaperanta ra (diperolehataudicatatpihaklain)dan sifatnyasalingmelengkapi.Data sekunder bentuknya berupa sumber daftar pustaka yang mendukung penelitian 
ilmiah serta diperoleh dari literatur yang relevan dari permasalahansebagaidasar pemahamanterhadapobjekpenelitiandan menganalisis secara tetap.

\section{Teknik Pengumpulan data}

Teknik pengumpulan data yang digunakan dalam penelitian ini adalah :

\section{Kuesioner}

Metode kuesioner merupakan teknik pengumpulan data yang dilakukan dengan cara memberikan pertanyaan secara tertulis kepada responden untuk dijawab.

\section{Studi Dokumentasi}

Teknik pengumpulan data dengan cara meninjau, membaca dan mempelajari berbagai macam buku, jurnal dan situs internet yang berhubungan dengan penelitian

\section{Populasi dan Sampel Penelitian Populasi}

Populasi diartikan sebagai keseluruhan subyek penelitian. Apabila seseorang penulis ingin meneliti semua relawan yang ada dalam wilayah penelitian, maka penelitiannya merupakan penelitian populasi (Arikunto, 2012: 115). Dengan demikian maka yang dimaksud dengan populasi adalah keseluruhan subyek berupa benda atau manusia yang dapat dipakai sebagai sampel penelitian.

\section{Sampel}

Sampel yaitu sebagian dari populasi karakteristik yang hendak diselidiki, dan dianggap bisa mewakili keseluruhan populasi tersebut Ps, Djarwanto dan Pangestu Subagyo $(2000,108)$. Berdasarkan kondisi populasi yang berjumlah 41orang, populasi kurang dari 100 orang. Menurut Andreas Priyono (2001:7) mengemukakan pada formal research teknik pengambilan sampel dilakukan secara cermat untuk mendapatkan sampel yang representatif.Sedangkan action reaserch tidak dibutuhkan teknis pengambilan sampel.

\section{Teknis Analisis Data}

Teknik analisis data yang digunakan dalam penelitian ini adalah:

\section{Analisa Deskriptif}

Menurut Ruslan (dalam Arikunto, 2002: 85) analisis deskriptif digunakan untuk menggambarkan karakteristik individu, situasi atau kelompok tertentu. Penelitiaan ini relatif sederhana yang tidak membutuhkan landasan teori yang rumit atau pengajuan hippotesis tertentu dan dalam penelitian ini analisis deskriptif digunakan untuk mendiskriptifkan data responden.

\section{Analisa Statistika}

Analisis kuantitatif adalah suatu analisis data yang diperoleh dari daftar pernyataan yang sudah diolah dalam bentuk angka dan pembahasannya melalui perhitungan statistik. Analisis kuantitatif ini terdiri atas beberapa tahap, yaitu :

a. Uji Validitas

Uji validitas ini dilakukan untuk mengetahui seberapa cermat suatu tes (alat ukur) melakukan fungsi ukurnya. Cara menguji validitas ini dilakukan dengan mengkorelasikan antara skor konstruk dengan skor totalnya. Adapun teknik korelasi yang diterapkan dalam penelitian ini adalah teknik Product moment correlationadalah sebagai berikut :

$R_{X Y}$

$$
=\frac{n\left(\sum X Y\right)-\left(\sum X\right)\left(\sum Y\right)}{\sqrt{\left\{n \sum X^{2}-\left(\sum X\right)^{2}\right\}\left\{n \sum Y^{2}-\left(\sum Y\right)^{2}\right\}}}
$$

Keterangan :

korelasi

$$
\text { Rxy }=\text { koefisien }
$$

$\mathrm{X}=$ skor butir 


$$
\begin{array}{ll}
\mathrm{Y} & =\text { skor faktor } \\
\mathrm{n} & =\text { jumlah responden }
\end{array}
$$

Dengan level of significance $95 \%$ maka bila :

$r$ hitung $>$ r table $(\alpha=0,05)$ berarti item tersebut sangat valid

$\mathrm{r}$ hitung $<\mathrm{r}$ table $(\alpha=0,05)$ berarti item tersebut tidak valid

Dikatakan valid apabila nilai $\mathrm{R}$ hitung lebih besar $(>$ ) dari R tabel (Sugiyono, 2012:118)

b. Uji realibilitas.

Analisis reliabilitas menunjukkan pada pengertian apakah instrumen dapat mengukur suatu yang diukur secara konsisten dari waktu ke waktu. Ukuran dikatakan reliabel jika ukuran tersebut memberikan hasil yang konsisten. Reliabel diukur dengan menggunakan metode Cronbach alpha. Rumus Cronbach alpha adalah sebagai berikut :

$\mathrm{R}=\left[\frac{k}{k-1}\right]\left[1-\frac{\sum \sigma_{b}{ }^{2}}{\sigma_{t}{ }^{2}}\right]$

\section{Keterangan :}

$\mathrm{R}=\quad$ reliabilitas

instrumen

$$
\mathrm{k}=\text { banyaknya butir }
$$

pertanyaaN

$$
\sum_{\sigma_{b}} 2=\text { jumlah varians butir }
$$

$\sigma_{t}^{2} \quad=$ varians total

Dikatakan reliabel apabila nilai Cronbach alpha lebih besar ( $>$ ) dari 0,60 (Sekaran, 2000; 173).

c. Uji Asumsi Klasik

1) Uji Normalitas

Pengujian ini dimaksudkan untuk mengetahui apakah dalam sebuah model regresi variabel dependen, variabel independen atau keduanya mempunyai distribusi normal atau tidak. Model regresi yang baik adalah distribusi data normal apabila :

a) Jika data menyebar disekitar garis diagonal dan mengikuti arah garis diagonal, maka model regresi tersebut memenuhi asumsi normalitas. b) Jika data menyebar jauh dari garis diagonal atau tidak mengikuti arah garis diagonal, maka model regresi tersebut tidak memenuhi asumsi normalitas.

2) Uji Heteroskedastisitas

Gejala heteroskedastisitas terjadi sebagai akibat dari variasiresidual yang tidak sama untuk semua pengamatan. Pada bagian ini, cara mendeteksi ada tidaknya heterokedastisitas dilakukan dengan melihat grafik plot antara nilai prediksi variabel terikat (Zpred) dengan residualnya (Sdired). Deteksi ada tidaknya gejala tersebut dapat dilakukan dengan melihat ada tidaknya pola tertentu pada grafik scatterplot (Ghozali, 2009;125). Dasar pengambilan analisis heterodastisitas adalah sebagai berikut :

a. Jika ada pola tertentu, seperti titik-titik yang ada membentuk pola tertentu yang teratur (bergelombang, melebar kemudian menyempit), maka sudah menunjukkan telah terjadi gejala heterodastisitas.

b. Jika tidak ada pola yang jelas, serta titik-titik menyebar di atas dan di bawah angka 0 pada sumbu Y, maka tidak terjadi heterodastisitas.

3) Uji Multikolinieritas

Uji multikolinieritas dilakukan untuk mengetahui korelasi antar variabelvariabel independen yang digunakan dalam penelitian. Uji Multikolinieritas dalam penelitian ini dapat diketahui dengan melihat angka variance inflation factor (VIF) dan tolerance. Menurut Ghozali (2009:147) model regresi dikatakan bebas dari multikolinieritas apabila memiliki nilai VIF lebih kecil dari angka 10 dan mempunyai angka toleransi lebih besar dari 0,10.

d. Analisa Regresi Linier berganda. 
Analisis ini digunakan untuk mengetahui besarnya pengaruh variabel independen terhadap variabel dependen, dengan asumsi variabel yang lain konstan. Rumusnya adalah (Arikunto, 2002:85). Rumusnya adalah sebagai berikut:

$\mathrm{Y}=\mathrm{a}+b_{1} x_{1}+b_{2} x_{2}+b_{3} x_{3}+\mathrm{e}$

Keterangan:

Y $=$ kinerja
$\mathrm{a}=$ konstanta
$b_{1} \quad=$ koefisien regresi untuk kepemimpinan

$b_{2} \quad=$ koefisien regresi untuk motivasi

$b_{3}=$ koefisien regresi untuk stres kerja

$$
\begin{aligned}
& x_{1} \quad=\text { kepemimpinan } \\
x_{2} & =\text { motivasi } \\
x_{3} \quad= & \text { stres kerja }
\end{aligned}
$$

error

$$
\mathrm{e}=
$$

e. Uji Hipotesis dengan :

Uji hipotesis dilakukan

1) Uji Parsial (Uji t)

Uji $t$ digunakan untuk menguji signifikan secara parsial pengaruh variabel independen $(\mathrm{X} 1)$ terhadap $(\mathrm{Y})$ dalam model regresi yang sudah dihasilkan. Dalam penelitian ini digunakan tingkat signifikansi $5 \%$ $(\alpha=0,05)$. Rumusnya adalah:

$$
T_{h i t}=\frac{r \sqrt{n-k-1}}{\sqrt{1-r^{2}}}
$$

Keterangan:

$\mathrm{r} \quad=$ koefisien korelasi parsial

$\mathrm{k}=$ jumlah variabel

independen

$\mathrm{n}=$ jumlah data/kasus

Kriteria uji $t$ adalah sebagai berikut (Ghozali, 2009: 91) :

a) Tidak ada pengaruh signifikan apabila t hitung $>0,05$

b) Terdapat pengaruh signifikan apabila $t$ hitung $<0,05$.

2) Uji Hipotesis Serentak (Uji F)
Uji $F$ digunakan untuk mengetahui tingkat signifikansi pengaruh variabel independen $(\mathrm{X})$ secara bersama-sama terhadap variabel dependen $(\mathrm{Y})$ dengan signifikansi $5 \% \quad(\alpha=0,05)$. Rumusnya adalah :

$$
F_{h i t}=\frac{r^{2} / k}{\left(1-r^{2} /(n-k-1)\right.}
$$

Keterangan:

$r^{2} \quad=$ koefisien determinasi

$\mathrm{n} \quad=$ jumlah data/kasus

$$
\mathrm{k}=\text { jumlah }
$$

variabel indepeden

Kriteria uji $\mathrm{F}$ adalah sebagai berikut (Ghozali, 2009: 91):

a) Apabila $\mathrm{F}$ hitung yang diperoleh dari hasil perhitungan regresi signifikansinya lebih kecil dari 0,05 maka hopotesis diterima.

b) Apabila $\mathrm{F}$ hitung yang diperoleh dari hasil perhitungan signifikansinya lebih besar dari 0,05 maka hipotesis ditolak.

f. Koefisien Determinasi $/ \mathrm{r}$ square Koefisien determinasi dipakai untuk mencari besaran prosentase kontribusi variabel bebas terhadap variabel terikat dengan melihat nilai $\mathrm{R}$ square. Koefisien determinasi pada regresi linearsering diartikan sebagai seberapa besar kemampuan semua variabel bebas dalam menjelaskan varians dari variabel terikatnya. Secara sederhana koefisien determinasi dihitung dengan mengkuadratkan Koefisien Korelasi (R). Koefisien determinasi dilambangkan dengan $r^{2}$. Nilai ini menyatakan proporsi variasi keseluruhan dalam nilai variabel dependen yang dapat diterangkan atau diakibatkan oleh hubungan linier dengan nilai variabel independen, selain itu diterangkan oleh peubah yang lain (galat atau peubah lainnya). 


\section{HASIL ANALISIS DAN PEMBAHASAN \\ Analisa Statistika}

Analisis kuantitatif adalah suatu analisis data yang diperoleh dari daftar pernyataan yang sudah diolah dalam bentuk angka dan pembahasannya melalui perhitungan statistik. Analisis kuantitatif ini terdiri atas beberapa tahap, yaitu :

g. Uji Validitas

Uji validitas ini dilakukan untuk mengetahui seberapa cermat suatu tes (alat ukur) melakukan fungsi ukurnya. Cara menguji validitas ini dilakukan dengan mengkorelasikan antara skor konstruk dengan skor totalnya. Adapun teknik korelasi yang diterapkan dalam penelitian ini adalah teknik Product moment correlation adalah sebagai berikut :

$$
\mathrm{R}_{\mathrm{XY}}=\frac{\mathrm{n}\left(\sum \mathrm{XY}\right)-\left(\sum \mathrm{X}\right)\left(\sum \mathrm{Y}\right)}{\sqrt{\left\{\mathrm{n} \sum \mathrm{X}^{2}-\left(\sum \mathrm{X}\right)^{2}\right\}\left\{\mathrm{n} \sum \mathrm{Y}^{2}-\left(\sum \mathrm{Y}\right)^{2}\right\}}}
$$

Keterangan :

$\mathrm{n} \quad=$ jumlah responden

$$
\begin{aligned}
\mathrm{Rxy} & =\text { koefisien korelasi } \\
\mathrm{X} & =\text { skor butir } \\
\mathrm{Y} & =\text { skor faktor }
\end{aligned}
$$

Dengan level of significance $95 \%$ maka bila :

$r$ hitung $>r$ table $(\alpha=0,05)$ berarti item tersebut sangat valid

$r$ hitung $<$ r table $(\alpha=0,05)$ berarti item tersebut tidak valid

Dikatakan valid apabila nilai R hitung lebih besar $(>$ ) dari R tabel (Sugiyono, 2012:118)

h. Uji realibilitas.

Analisis reliabilitas menunjukkan pada pengertian apakah instrumen dapat mengukur suatu yang diukur secara konsisten dari waktu ke waktu. Ukuran dikatakan reliabel jika ukuran tersebut memberikan hasil yang konsisten. Reliabel diukur dengan menggunakan metode Cronbach alpha. Rumus Cronbach alpha adalah sebagai berikut :

$$
\begin{gathered}
\mathrm{R}=\left[\frac{\mathrm{k}}{\mathrm{k}-1}\right]\left[1-\frac{\sum_{\sigma_{\mathrm{b}}}{ }^{2}}{\sigma_{\mathrm{t}}{ }^{2}}\right] \\
\mathrm{R} \quad \frac{\text { Keterangan : }}{\text { reliabilitas instrumen }} \\
\mathrm{k}=\text { banyaknya butir pertanyaaN } \\
\sum_{\sigma_{\mathrm{b}}} 2 \quad=\text { jumlah varians butir } \\
\sigma_{\mathrm{t}}{ }^{2}=\text { varians total }
\end{gathered}
$$

Dikatakan reliabel apabila nilai Cronbach alpha lebih besar (>) dari 0,60 (Sekaran, 2000; 173).

i. Uji Asumsi Klasik

4) Uji Normalitas

Pengujian ini dimaksudkan untuk mengetahui apakah dalam sebuah model regresi variabel dependen, variabel independen atau keduanya mempunyai distribusi normal atau tidak. Model regresi yang baik adalah distribusi data normal apabila :

c) Jika data menyebar disekitar garis diagonal dan mengikuti arah garis diagonal, maka model regresi tersebut memenuhi asumsi normalitas.

d) Jika data menyebar jauh dari garis diagonal atau tidak mengikuti arah garis diagonal, maka model regresi tersebut tidak memenuhi asumsi normalitas.

5) Uji Heteroskedastisitas 
Gejala heteroskedastisitas terjadi sebagai akibat dari variasi residual yang tidak sama untuk semua pengamatan. Pada bagian ini, cara mendeteksi ada tidaknya heterokedastisitas dilakukan dengan melihat grafik plot antara nilai prediksi variabel terikat (Zpred) dengan residualnya (Sdired). Deteksi ada tidaknya gejala tersebut dapat dilakukan dengan melihat ada tidaknya pola tertentu pada grafik scatterplot (Ghozali, 2009;125). Dasar pengambilan analisis heterodastisitas adalah sebagai berikut :

c. Jika ada pola tertentu, seperti titik-titik yang ada membentuk pola tertentu yang teratur (bergelombang, melebar kemudian menyempit), maka sudah menunjukkan telah terjadi gejala heterodastisitas.

d. Jika tidak ada pola yang jelas, serta titik-titik menyebar di atas dan di bawah angka 0 pada sumbu Y, maka tidak terjadi heterodastisitas.

6) Uji Multikolinieritas

Uji multikolinieritas dilakukan untuk mengetahui korelasi antar variabel-variabel independen yang digunakan dalam penelitian. Uji Multikolinieritas dalam penelitian ini dapat diketahui dengan melihat angka variance inflation factor (VIF) dan tolerance. Menurut Ghozali (2009:147) model regresi dikatakan bebas dari multikolinieritas apabila memiliki nilai VIF lebih kecil dari angka 10 dan mempunyai angka toleransi lebih besar dari 0,10 .

j. Analisa Regresi Linier berganda.

Analisis ini digunakan untuk mengetahui besarnya pengaruh variabel independen terhadap variabel dependen, dengan asumsi variabel yang lain konstan. Rumusnya adalah (Arikunto, 2002:85). Rumusnya adalah sebagai berikut:

$\mathrm{Y}=\mathrm{a}+\mathrm{b}_{1} \mathrm{x}_{1}+\mathrm{b}_{2} \mathrm{x}_{2}+\mathrm{b}_{3} \mathrm{x}_{3}+\mathrm{e}$

Keterangan:

$\mathrm{a} \quad=$ konstanta

$=$ kinerja

$\mathrm{b}_{1}=$ koefisien regresi untuk kepemimpinan

$\mathrm{b}_{2} \quad=$ koefisien regresi untuk motivasi

$\mathrm{b}_{3}=$ koefisien regresi untuk stres kerja

$\mathrm{x}_{1}=$ kepemimpinan

$\mathrm{x}_{2} \quad$ motivasi

$\mathrm{x}_{3} \quad=$ stres kerja

e $\quad=$ error

k. Uji Hipotesis

Uji hipotesis dilakukan dengan :

3) Uji Parsial (Uji t)

Uji t digunakan untuk menguji signifikan secara parsial pengaruh variabel independen (X1) terhadap (Y) dalam model regresi yang sudah dihasilkan. Dalam penelitian ini digunakan tingkat signifikansi 5\% $(\alpha=0,05)$. Rumusnya adalah:

$$
\mathrm{T}_{\text {hit }}=\frac{\mathrm{r} \sqrt{\mathrm{n}-\mathrm{k}-1}}{\sqrt{1-\mathrm{r}^{2}}}
$$

Keterangan:

$\mathrm{r} \quad=$ koefisien korelasi parsial

$\mathrm{k}=$ jumlah variabel independen

$\mathrm{n} \quad=$ jumlah data/kasus

Kriteria uji $\mathrm{t}$ adalah sebagai berikut (Ghozali, 2009: 91) : 
c) Tidak ada pengaruh signifikan apabila t hitung $>0,05$

d) Terdapat pengaruh signifikan apabila t hitung $<0,05$.

4) Uji Hipotesis Serentak (Uji F)

Uji $\mathrm{F}$ digunakan untuk mengetahui tingkat signifikansi pengaruh variabel independen (X) secara bersama-sama terhadap variabel dependen $(Y)$ dengan signifikansi $5 \%(\alpha=0,05)$. Rumusnya adalah :

$$
\begin{gathered}
\mathrm{F}_{\text {hit }}=\frac{\mathrm{r}^{2} / \mathrm{k}}{\left(1-\mathrm{r}^{2} /(\mathrm{n}-\mathrm{k}-1)\right.} \\
\mathrm{r}^{2}=\underset{\text { Keterangan: }}{\text { koefisien determinasi }} \\
\mathrm{n}=\begin{array}{c}
\text { jumlah data/kasus } \\
\mathrm{k} \quad=\text { jumlah variabel indepeden }
\end{array}
\end{gathered}
$$

Kriteria uji F adalah sebagai berikut (Ghozali, 2009: 91):

c) Apabila $\mathrm{F}$ hitung yang diperoleh dari hasil perhitungan regresi signifikansinya lebih kecil dari 0,05 maka hopotesis diterima.

d) Apabila $\mathrm{F}$ hitung yang diperoleh dari hasil perhitungan signifikansinya lebih besar dari 0,05 maka hipotesis ditolak.

1. Koefisien Determinasi/r square

Koefisien determinasi dipakai untuk mencari besaran prosentase kontribusi variabel bebas terhadap variabel terikat dengan melihat nilai $\mathrm{R}$ square. Koefisien determinasi pada regresi linearsering diartikan sebagai seberapa besar kemampuan semua variabel bebas dalam menjelaskan varians dari variabel terikatnya. Secara sederhana koefisien determinasi dihitung dengan mengkuadratkan Koefisien Korelasi (R). Koefisien determinasi dilambangkan dengan $r^{2}$. Nilai ini menyatakan proporsi variasi keseluruhan dalam nilai variabel dependen yang dapat diterangkan atau diakibatkan oleh hubungan linier dengan nilai variabel independen, selain itu diterangkan oleh peubah yang lain (galat atau peubah lainnya).

\section{HASIL ANALISIS DAN PEMBAHASAN Analisa Statistika}

Analisis kuantitatif adalah suatu analisis data yang diperoleh dari daftar pernyataan yang sudah diolah dalam bentuk angka dan pembahasannya melalui perhitungan statistik. Analisis kuantitatif ini terdiri atas beberapa tahap, yaitu :

\section{Uji Validitas}

Uji validitas ini dilakukan untuk mengetahui seberapa cermat suatu tes (alat ukur) melakukan fungsi ukurnya. Cara menguji validitas ini dilakukan dengan mengkorelasikan antara skor konstruk dengan skor totalnya. Adapun teknik korelasi yang diterapkan dalam penelitian ini adalah teknik Product moment correlation adalah sebagai berikut :

Keterangan :

$$
R_{X Y}=\frac{n\left(\sum X Y\right)-\left(\sum X\right)\left(\sum Y\right)}{\sqrt{\left\{n \sum X^{2}-\left(\sum X\right)^{2}\right\}\left\{n \sum Y^{2}-\left(\sum Y\right)^{2}\right\}}}
$$

Rxy $=$ koefisien korelasi

$\mathrm{X} \quad=$ skor butir 


$$
\begin{aligned}
\mathrm{Y} & =\text { skor faktor } \\
\mathrm{n} & =\text { jumlah responden }
\end{aligned}
$$

Dengan level of significance $95 \%$ maka bila :

$r$ hitung $>r$ table $(\alpha=0,05)$ berarti item tersebut sangat valid

$r$ hitung $<\mathrm{r}$ table $(\alpha=0,05)$ berarti item tersebut tidak valid

Dikatakan valid apabila nilai $\mathrm{R}$ hitung lebih besar $(>$ ) dari R tabel (Sugiyono, 2012:118)

\section{Uji realibilitas.}

Analisis reliabilitas menunjukkan pada pengertian apakah instrumen dapat mengukur suatu yang diukur secara konsisten dari waktu ke waktu. Ukuran dikatakan reliabel jika ukuran tersebut memberikan hasil yang konsisten. Reliabel diukur dengan menggunakan metode Cronbach alpha. Rumus Cronbach alpha adalah sebagai berikut :

$$
\begin{array}{ll}
\mathrm{R} & =\left[\frac{k}{k-1}\right]\left[1-\frac{\sum_{\sigma_{b}} 2}{\sigma_{t}{ }^{2}}\right] \\
\text { Keterangan : } & \\
\mathrm{R} \quad=\text { reliabilitas instrumen } \\
\mathrm{k} \quad=\text { banyaknya butir pertanyaaN } \\
\sum_{\sigma_{b}} 2=\text { jumlah varians butir } \\
\sigma_{t}{ }^{2} \quad=\text { varians total }
\end{array}
$$

Dikatakan reliabel apabila nilai Cronbach alpha lebih besar (>) dari 0,60 (Sekaran, 2000; 173).

\section{Uji Asumsi Klasik \\ Uji Normalitas}

Pengujian ini dimaksudkan untuk mengetahui apakah dalam sebuah model regresi variabel dependen, variabel independen atau keduanya mempunyai distribusi normal atau tidak. Model regresi yang baik adalah distribusi data normal apabila :

a) Jika data menyebar disekitar garis diagonal dan mengikuti arah garis diagonal, maka model regresi tersebut memenuhi asumsi normalitas.

b) Jika data menyebar jauh dari garis diagonal atau tidak mengikuti arah garis diagonal, maka model regresi tersebut tidak memenuhi asumsi normalitas.

\section{Uji Heteroskedastisitas}

Gejala heteroskedastisitas terjadi sebagai akibat dari variasi residual yang tidak sama untuk semua pengamatan. Pada bagian ini, cara mendeteksi ada tidaknya heterokedastisitas dilakukan dengan melihat grafik plot antara nilai prediksi variabel terikat (Zpred) dengan residualnya (Sdired). Deteksi ada tidaknya gejala tersebut dapat dilakukan dengan melihat ada tidaknya pola tertentu pada grafik scatterplot (Ghozali, 2009;125). Dasar pengambilan analisis heterodastisitas adalah sebagai berikut :

a. Jika ada pola tertentu, seperti titik-titik yang ada membentuk pola tertentu yang teratur (bergelombang, melebar kemudian menyempit), maka sudah menunjukkan telah terjadi gejala heterodastisitas.

b. Jika tidak ada pola yang jelas, serta titik-titik menyebar di atas dan di bawah angka 0 pada sumbu Y, maka tidak terjadi heterodastisitas. 


\section{Uji Multikolinieritas}

Uji multikolinieritas dilakukan untuk mengetahui korelasi antar variabel-variabel independen yang digunakan dalam penelitian. Uji Multikolinieritas dalam penelitian ini dapat diketahui dengan melihat angka variance inflation factor (VIF) dan tolerance. Menurut Ghozali (2009:147) model regresi dikatakan bebas dari multikolinieritas apabila memiliki nilai VIF lebih kecil dari angka 10 dan mempunyai angka toleransi lebih besar dari 0,10.

Analisa Regresi Linier berganda.

Analisis ini digunakan untuk mengetahui besarnya pengaruh variabel independen terhadap variabel dependen, dengan asumsi variabel yang lain konstan. Rumusnya adalah (Arikunto, 2002:85). Rumusnya adalah sebagai berikut:

$$
\begin{aligned}
& \mathrm{Y}=\mathrm{a}+b_{1} x_{1}+b_{2} x_{2}+b_{3} x_{3}+\mathrm{e} \\
& \text { Keterangan: } \\
& \mathrm{Y}=\text { kinerja } \\
& \text { a }=\text { konstanta } \\
& b_{1}=\text { koefisien regresi untuk kepemimpinan } \\
& b_{2} \quad=\text { koefisien regresi untuk motivasi } \\
& b_{3}=\text { koefisien regresi untuk stres kerja } \\
& x_{1}=\text { kepemimpinan } \\
& x_{2}=\text { motivasi } \\
& x_{3}=\text { stres kerja } \\
& \text { error }
\end{aligned}
$$

\section{Uji Hipotesis}

Uji hipotesis dilakukan dengan :

\section{Uji Parsial (Uji t)}

Uji t digunakan untuk menguji signifikan secara parsial pengaruh variabel independen (X1) terhadap (Y) dalam model regresi yang sudah dihasilkan. Dalam penelitian ini digunakan tingkat signifikansi 5\% $(\alpha=0,05)$. Rumusnya adalah:

$$
T_{\text {hit }}=\frac{r \sqrt{n-k-1}}{\sqrt{1-r^{2}}}
$$

Keterangan:

$\mathrm{r} \quad=$ koefisien korelasi parsial

$\mathrm{k} \quad$ = jumlah variabel independen

$\mathrm{n} \quad=$ jumlah data/kasus

Kriteria uji t adalah sebagai berikut (Ghozali, 2009: 91) :

e) Tidak ada pengaruh signifikan apabila t hitung $>0,05$

f) Terdapat pengaruh signifikan apabila thitung $<0,05$.

\section{Uji Hipotesis Serentak (Uji F)}

Uji F digunakan untuk mengetahui tingkat signifikansi pengaruh variabel independen $(\mathrm{X})$ secara bersama-sama terhadap variabel dependen (Y) dengan signifikansi 5\% $(\alpha=0,05)$. Rumusnya adalah : 


$$
F_{\text {hit }}=\frac{r^{2} / k}{\left(1-r^{2} /(n-k-1)\right.}
$$

Keterangan:

$$
\begin{array}{ll}
r^{2} & =\text { koefisien determinasi } \\
\mathrm{n} & =\text { jumlah data/kasus } \\
\mathrm{k} & =\text { jumlah variabel indepeden }
\end{array}
$$

Kriteria uji F adalah sebagai berikut (Ghozali, 2009: 91):

a) Apabila $\mathrm{F}$ hitung yang diperoleh dari hasil perhitungan regresi signifikansinya lebih kecil dari 0,05 maka hopotesis diterima.

b) Apabila $\mathrm{F}$ hitung yang diperoleh dari hasil perhitungan signifikansinya lebih besar dari 0,05 maka hipotesis ditolak.

\section{Koefisien Determinasi/r square}

Koefisien determinasi dipakai untuk mencari besaran prosentase kontribusi variabel bebas terhadap variabel terikat dengan melihat nilai $\mathrm{R}$ square. Koefisien determinasi pada regresi linearsering diartikan sebagai seberapa besar kemampuan semua variabel bebas dalam menjelaskan varians dari variabel terikatnya. Secara sederhana koefisien determinasi dihitung dengan mengkuadratkan Koefisien Korelasi (R). Koefisien determinasi dilambangkan dengan $r^{2}$. Nilai ini menyatakan proporsi variasi keseluruhan dalam nilai variabel dependen yang dapat diterangkan atau diakibatkan oleh hubungan linier dengan nilai variabel independen, selain itu diterangkan oleh peubah yang lain (galat atau peubah lainnya).

\section{Uji Validitas}

Kuesioner dinyatakan valid apabila pernyataan yang diajukan pada kuesioner tersebut mampu mengungkap sesuatu yang akan diukur pada kuesioner tersebut. Untuk mengukur validitas variabel teknik korelasi yang diterapkan dalam penelitian ini adalah teknik Product moment correlation, dengan taraf signifikansi 5\%. Jika signifikansi dibawah 0,05 berarti butir pernyataan dinyatakan valid dan jika signifikansi diatas 0,05 berarti tidak valid.

1. Variabel Kepemimpinan $\left(\mathrm{X}_{1}\right)$

Hasil uji validitas Kepemimpinan dijelaskan sebagai berikut:

Tabel IV.4

Hasil Uji Validitas Variabel Kepemimpinan

\begin{tabular}{|c|c|c|c|l|}
\hline Butir & $\begin{array}{c}\mathrm{r} \\
\text { hitung }\end{array}$ & $\mathrm{r}$ tabel & $\begin{array}{c}\text { Syarat } \\
\text { signifikansi }\end{array}$ & \multicolumn{1}{|c|}{ Status } \\
\hline 1 & 0,637 & 0,304 & $<0,05$ & Valid \\
\hline 2 & 0,539 & 0,304 & $<0,05$ & Valid \\
\hline 3 & 0,467 & 0,304 & $<0,05$ & Valid \\
\hline 4 & $-0,078$ & 0,304 & $<0,05$ & Tidak Valid \\
\hline 5 & 0,458 & 0,304 & $<0,05$ & Valid \\
\hline 6 & 0,670 & 0,304 & $<0,05$ & Valid \\
\hline 7 & 0,317 & 0,304 & $<0,05$ & Valid \\
\hline 8 & 0,548 & 0,304 & $<0,05$ & Valid \\
\hline 9 & 0,578 & 0,304 & $<0,05$ & Valid \\
\hline 10 & 0,361 & 0,304 & $<0,05$ & Valid \\
\hline
\end{tabular}


Sumber : data primer diolah, 2015

Hasil validitas setelah butir tidak valid dikeluarkan

\begin{tabular}{|c|c|c|c|c|}
\hline Butir & $\begin{array}{c}\mathrm{r} \\
\text { hitung }\end{array}$ & $\mathrm{r}$ tabel & $\begin{array}{c}\text { Syarat } \\
\text { signifikansi }\end{array}$ & Status \\
\hline 1 & 0,625 & 0,304 & $<0,05$ & Valid \\
\hline 2 & 0,527 & 0,304 & $<0,05$ & Valid \\
\hline 3 & 0,460 & 0,304 & $<0,05$ & Valid \\
\hline 4 & 0,472 & 0,304 & $<0,05$ & Valid \\
\hline 5 & 0,692 & 0,304 & $<0,05$ & Valid \\
\hline 6 & 0,335 & 0,304 & $<0,05$ & Valid \\
\hline 7 & 0,576 & 0,304 & $<0,05$ & Valid \\
\hline 8 & 0,563 & 0,304 & $<0,05$ & Valid \\
\hline 9 & 0,411 & 0,304 & $<0,05$ & Valid \\
\hline
\end{tabular}

Dari tabel diatas dapat dijelaskan bahwa signifikansi $<0,05$, sehingga semua item pernyataan yang dipakai pada variabel ini dinyatakan valid (sah). Kecuali butir ke 4 pada variabel kepemimpinan sehingga tidak dipakai didalam uji regresi.

2. Variabel Motivasi $\left(\mathrm{X}_{2}\right)$

Uji validitas Motivasi dijelaskan sebagai berikut:

Tabel IV.5

Hasil Uji Validitas Motivasi

\begin{tabular}{|c|c|c|c|c|}
\hline Butir & $\mathrm{r}$ hitung & $\mathrm{r}$ tabel & $\begin{array}{c}\text { Syarat } \\
\text { signifikansi }\end{array}$ & Status \\
\hline 1 & 0,261 & 0,304 & $<0,05$ & Tidak Valid \\
\hline 2 & 0,540 & 0,304 & $<0,05$ & Valid \\
\hline 3 & 0,550 & 0,304 & $<0,05$ & Valid \\
\hline 4 & 0,691 & 0,304 & $<0,05$ & Valid \\
\hline 5 & 0,631 & 0,304 & $<0,05$ & Valid \\
\hline 6 & 0,469 & 0,304 & $<0,05$ & Valid \\
\hline 7 & 0,546 & 0,304 & $<0,05$ & Valid \\
\hline 8 & 0,585 & 0,304 & $<0,05$ & Valid \\
\hline 9 & 0,441 & 0,304 & $<0,05$ & Valid \\
\hline 10 & 0,580 & 0,304 & $<0,05$ & Valid \\
\hline
\end{tabular}

Sumber : data primer diolah, 2015

Hasil validitas setelah butir tidak valid dikeluarkan

\begin{tabular}{|c|c|c|c|l|}
\hline Butir & $\begin{array}{c}\mathrm{r} \\
\text { hitung }\end{array}$ & $\mathrm{r}$ tabel & $\begin{array}{c}\text { Syarat } \\
\text { signifikansi }\end{array}$ & \multicolumn{1}{|c|}{ Status } \\
\hline 1 & 0,513 & 0,304 & $<0,05$ & Valid \\
\hline 2 & 0,571 & 0,304 & $<0,05$ & Valid \\
\hline 3 & 0,705 & 0,304 & $<0,05$ & Valid \\
\hline 4 & 0,623 & 0,304 & $<0,05$ & Valid \\
\hline 5 & 0,478 & 0,304 & $<0,05$ & Valid \\
\hline 6 & 0,541 & 0,304 & $<0,05$ & Valid \\
\hline
\end{tabular}




\begin{tabular}{|l|l|l|l|l|}
\hline 7 & 0,593 & 0,304 & $<0,05$ & Valid \\
\hline 8 & 0,470 & 0,304 & $<0,05$ & Valid \\
\hline 9 & 0,570 & 0,304 & $<0,05$ & Valid \\
\hline
\end{tabular}

Dari tabel diatas dapat dijelaskan bahwa signifikansi $<0,05$, sehingga semua item pernyataan yang dipakai pada variabel ini dinyatakan valid (sah). Kecuali butir ke 1 pada varibel motivasi sehingga tidak dipakai didalam uji regresi.

3. Variabel Stres Kerja $\left(\mathrm{X}_{3}\right)$

Analisis uji validitas Lingkungan kerja dijelaskan sebagai berikut :

Tabel 1V.6

Hasil Uji Validitas Stres Kerja

\begin{tabular}{|c|c|c|c|c|}
\hline Butir & r hitung & r tabel & $\begin{array}{c}\text { Syarat } \\
\text { signifikansi }\end{array}$ & Status \\
\hline 1 & 0,625 & 0,304 & $<0,05$ & Valid \\
\hline 2 & 0,565 & 0,304 & $<0,05$ & Valid \\
\hline 3 & 0,597 & 0,304 & $<0,05$ & Valid \\
\hline 4 & 0,535 & 0,304 & $<0,05$ & Valid \\
\hline 5 & 0,264 & 0,304 & $<0,05$ & Tidak Valid \\
\hline 6 & 0,369 & 0,304 & $<0,05$ & Valid \\
\hline 7 & 0,449 & 0,304 & $<0,05$ & Valid \\
\hline 8 & 0,503 & 0,304 & $<0,05$ & Valid \\
\hline 9 & 0,603 & 0,304 & $<0,05$ & Valid \\
\hline
\end{tabular}

Sumber : data primer diolah, 2015

Hasil validitas setelah butir tidak valid dikeluarkan

\begin{tabular}{|c|c|c|c|c|}
\hline Butir & $\begin{array}{c}\mathrm{r} \\
\text { hitung }\end{array}$ & $\mathrm{r}$ tabel & $\begin{array}{c}\text { Syarat } \\
\text { signifikansi }\end{array}$ & Status \\
\hline 1 & 0,639 & 0,304 & $<0,05$ & Valid \\
\hline 2 & 0,591 & 0,304 & $<0,05$ & Valid \\
\hline 3 & 0,591 & 0,304 & $<0,05$ & Valid \\
\hline 4 & 0,540 & 0,304 & $<0,05$ & Valid \\
\hline 5 & 0,375 & 0,304 & $<0,05$ & Valid \\
\hline 6 & 0,457 & 0,304 & $<0,05$ & Valid \\
\hline 7 & 0,461 & 0,304 & $<0,05$ & Valid \\
\hline 8 & 0,622 & 0,304 & $<0,05$ & Valid \\
\hline
\end{tabular}

Dari tabel diatas dapat dijelaskan bahwa signifikansi $<0,05$, sehingga semua item pernyataan yang dipakai pada variabel ini dinyatakan valid (sah). Kecuali butir ke 5 pada variabel stres kerja sehingga tidak dipakai didalam uji regresi.

4. Variabel Kinerja Karyawan (Y)

Hasil analisis uji validitas variabel semangat kerja sebagai berikut:

Tabel IV.7

Hasil Uji Validitas Kinerja Karyawan 


\begin{tabular}{|c|c|c|c|c|}
\hline Butir & r hitung & $\mathrm{r}$ tabel & $\begin{array}{c}\text { Syarat } \\
\text { signifikansi }\end{array}$ & Status \\
\hline 1 & 0,605 & 0,304 & $<0,05$ & Valid \\
\hline 2 & 0,520 & 0,304 & $<0,05$ & Valid \\
\hline 3 & 0,515 & 0,304 & $<0,05$ & Valid \\
\hline 4 & 0,504 & 0,304 & $<0,05$ & Valid \\
\hline 5 & 0,438 & 0,304 & $<0,05$ & Valid \\
\hline 6 & 0,645 & 0,304 & $<0,05$ & Valid \\
\hline 7 & 0,323 & 0,304 & $<0,05$ & Valid \\
\hline 8 & 0,536 & 0,304 & $<0,05$ & Valid \\
\hline 9 & 0,556 & 0,304 & $<0,05$ & Valid \\
\hline 10 & 0,385 & 0,304 & $<0,05$ & Valid \\
\hline
\end{tabular}

Sumber : data primer diolah, 2015

Dari tabel diatas dapat dijelaskan bahwa signifikansi $<0,05$, sehingga semua item pernyataan yang dipakai pada variabel ini dinyatakan valid (sah).

\section{Uji Reliabilitas}

Uji reliabilitas butir dilakukan dengan ketentuan, jika $\mathrm{r}$ alpha cronbach $>0,60$ maka variabel tersebut reliabel dan sebaliknya jika $\mathrm{r}$ alpha cronbach $<0,60$ maka variabel tersebut tidak reliabel (Sekaran, 2000;173).

Tabel 1V.8

Hasil Uji Reliabilitas

\begin{tabular}{|l|c|c|c|}
\hline \multicolumn{1}{|c|}{ Variabel } & cut off & $\mathrm{r}$ alpha & Status \\
\hline Kepemimpinan & 0,60 & 0,589 & Reliabel \\
\hline Motivasi & 0,60 & 0,724 & Reliabel \\
\hline Stres Kerja & 0,60 & 0,622 & Reliabel \\
\hline Kinerja Karyawan & 0,60 & 0,671 & Reliabel \\
\hline
\end{tabular}

Sumber : Data Primer Diolah, 2015

Berdasarkan tabel diatas, hasil analisis dapat dijelaskan bahwa seluruh variabel yang dipakai dalam penelitian ini dinyatakan reliabel (andal) karena $r$ alphanya lebih besar dari 0,60

\section{Uji Asumsi Klasik}

Multikolinieritas

Hasil uji mulikolinearitas dapat dilihat pada tabel berikut :

Gambar IV.1

Uji Multikolinearitas

\begin{tabular}{|r|r|}
\hline \multicolumn{2}{|c|}{ Collinearity Statistics } \\
\hline Tolerance & VIF \\
\hline & \\
.665 & 1.503 \\
.732 & 1.366 \\
.893 & 1.119 \\
\hline
\end{tabular}


Sumber : Data Primer Diolah, 2015

Berdasarkan tabel diatas dapat dijelaskan bahwa pada bagian collinearity statistic menunjukan bahwa angka VIF dibawah 10 dan tolerance diatas 0,1 . Karena itu model regresi ini tidak terdapat multikolinieritas, sehingga model regresi dapat dipakai (Ghozali, 2009:147).

\section{Heteroskedastisitas}

Pengujian ini dilakukan untuk menguji apakah dalam sebuah model regresi terjadi ketidaksamaan varian dan residual disuatu pengamatan ke pengamatan yang lain. Hasil analisis diperoleh sebagai berikut :

\section{Gambar IV.2}

Uji Heteroskedastisitas

Scatterplot

Dependent Variable: $Y$

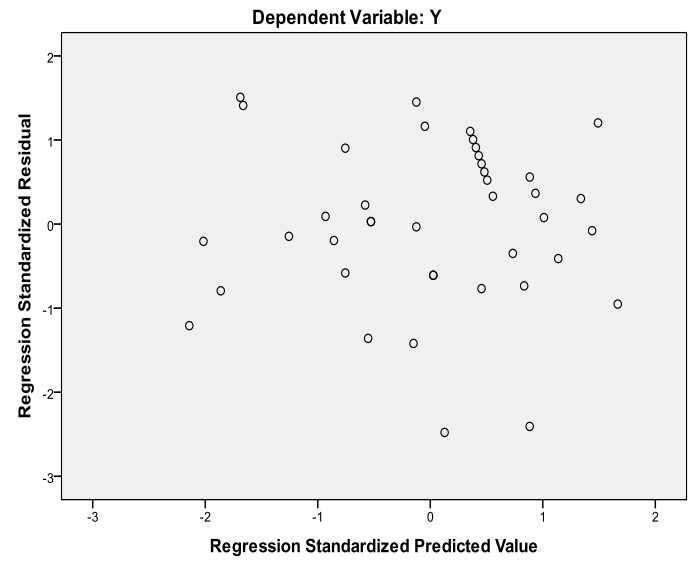

Sumber : Data Primer Diolah, 2015

Berdasarkan gambar grafik diatas, menunjukan bahwa tidak ada pola tertentu, seperti titik-titik yang membentuk suatu pola tertentu yang teratur (bergelombang, melebar, kemudian menyempit) dan tidak ada pola yang jelas sehingga dapat disimpulkan model regresi dalam penelitian ini tidak terjadi heteroskedastisitas (Ghozali, 2009:125).

\section{Normalitas}

Analisis ini untuk menguji apakah data sebuah model regresi, antara variabel dependen dan variabel independen/ keduanya mempunyai distribusi normal $/$ mendekati normal.

Gambar IV.3

\section{Uji Normalitas}

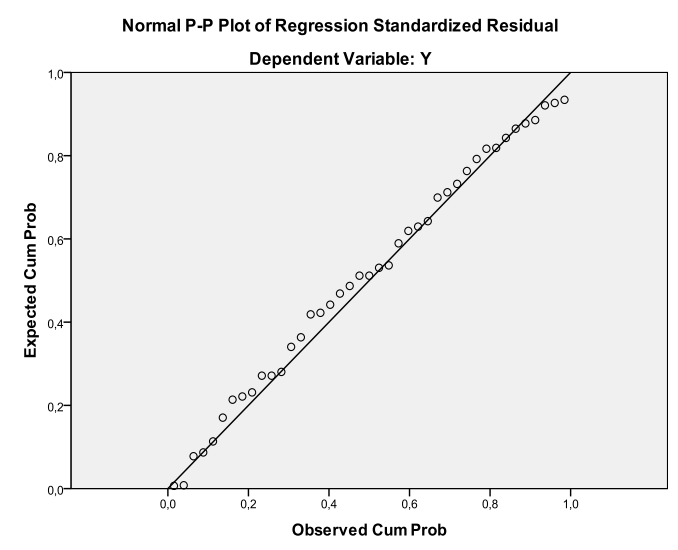


Sumber : Data Primer Diolah, 2015

Berdasarkan gambar grafik uji normalitas terlihat bahwa data menyebar disekitar garis diagonal dan mengikuti arah garis diagonal. Maka model regresi memenuhi asumsi normalitas (Ghozali, 2009:96).

\section{Analisis Regresi}

Analisis ini digunakan untuk mengetahui besar pengaruh dari variabel-variabel bebas terhadap semua variabel terikat yang ada dalam penelitian ini dengan menggunakan rumus sebagai berikut (Arikunto, 2002: 85) :

$$
\mathrm{Y}=\mathrm{a}+\mathrm{b}_{1} \mathrm{X}_{1}+\mathrm{b}_{2} \mathrm{X}_{2}+\mathrm{b}_{3} \mathrm{X}_{3}+\mathrm{e}
$$

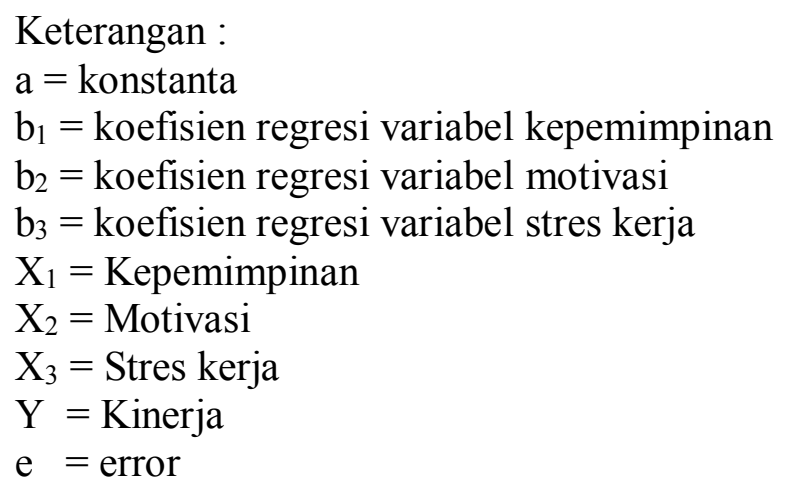

Adapun hasil dari perhitungannya adalah sebagai berikut :

Gambar IV.4

Regresi Berganda Hasil Perhitungan Program SPSS

\begin{tabular}{|c|c|c|c|c|c|c|}
\hline \multicolumn{7}{|c|}{ Coefficients $^{\mathrm{a}}$} \\
\hline & \multirow[b]{2}{*}{ Model } & \multicolumn{2}{|c|}{ Unstandardized Coefficients } & \multirow{2}{*}{$\begin{array}{c}\text { Standardized } \\
\text { Coefficients } \\
\text { Beta }\end{array}$} & \multirow[b]{2}{*}{$\mathrm{t}$} & \multirow[b]{2}{*}{ Sig. } \\
\hline & & $B$ & Std. Error & & & \\
\hline \multirow[t]{4}{*}{1} & (Constant) (a) & $-3,498$ & 2.095 & & -.1669 & .103 \\
\hline & Kepemimpinan (X1) & 1,042 & .056 & .912 & 18,580 & .000 \\
\hline & Motivasi (X2) & .129 & .049 & .124 & 2.658 & .012 \\
\hline & Stres Kerja (X3) & -.065 & .069 & -.040 & -.945 & .351 \\
\hline
\end{tabular}

a. Dependent Variable: Kinerja $(\mathrm{Y})$

Sumber : Data Primer Diolah, 2015

Berdasarkan tabel di atas, maka dapat dibuat persamaan regresinya sebagai berikut :

$$
\mathrm{Y}=-3,498+1,042 \mathrm{X}_{1}+0,129 \mathrm{X}_{2}-0,065 \mathrm{X}_{3}+\mathrm{e}
$$

Kemudian nilai-nilai $a, b_{1}, b_{2}$ dan $b_{3}$ dijelaskan sebagai berikut :

1. Konstanta (a) $=-3,498$

Menunjukkan nilai konstanta atau nilai tetap kinerja yang tidak terpengaruh oleh variabel kepemimpinan, motivasi dan stres kerja, maka nilai kinerja sebesar 3,498 poin.

2. Variabel Independen 
a. $b_{1}=1,042$

Koefisien regresi untuk $X_{1}$ sebesar 1,042 , artinya setiap penambahan 1 poin pada variabel kepemimpinan $\left(\mathrm{X}_{1}\right)$ maka akan meningkatkan kinerja sebesar 1,042 poin, apabila variabel independen lain nilainya tetap.

b. $\mathrm{b}_{2}=0,129$

Koefisien regresi untuk $\mathrm{X}_{2}$ sebesar 0,129 , artinya setiap penambahan 1 poin pada variabel motivasi $\left(\mathrm{X}_{2}\right)$ maka akan meningkatkan kinerja sebesar 0,129 poin, apabila variabel independen lain nilainya tetap.

c. $b_{3}=-0,065$

Koefisien regresi untuk $X_{3}$ sebesar -0,065, artinya setiap penambahan 1 poin pada stres kerja $\left(\mathrm{X}_{3}\right)$ maka akan menurunkan kinerja sebesar $-0,065$ poin, apabila variabel independen lain nilainya tetap.

\section{Uji Parsial (Uji t)}

Pengujian ini digunakan untuk mengetahui tingkat signifikansi tiap variabel independen, dengan ketentuan (Ghozali, 2009: 91):

1. Jika probalilitas $>0,05$ maka koefisien regresi tidak signifikan

2. Jika probalilitas $<0,05$ maka koefisien regresi signifikan

Untuk mengetahui hasil analisis uji $\mathrm{t}$ dalam penelitian ini dapat dilihat pada Tabel IV.4 Gambar tersebut menunjukkan hal berikut:

1. Variabel Kepemimpinan

Dari Gambar IV.4 menunjukkan bahwa hasil $t_{\text {hitung }}$ sebesar 18,580 dengan tingkat signifikan $0,000<0,05$ ini berarti variabel kepemimpinan berpengaruh signifikan terhadap kinerja.

2. Variabel Motivasi

Dari Gambar IV.4 menunjukkan bahwa hasil thitung sebesar 2,658 dengan tingkat signifikan $0,012<0,05$ yang berarti variabel motivasi berpengaruh signifikan terhadap kinerja.

3. Variabel Stres Kerja

Dari Gambar IV.4 di atas menunjukkan bahwa hasil thitung sebesar -0,945 dengan tingkat signifikan $0,351>0,05$ yang berarti variabel stres kerja tidak berpengaruh signifikan terhadap kinerja.

\section{Uji Simultan (Uji F)}

Hasil uji F program SPSS dapat diterangkan dengan tabel berikut:

\section{Gambar IV.5}

Uji Simultan

\section{ANOVA $^{b}$}

\begin{tabular}{|l|r|r|r|r|r|}
\hline Model & Sum of Squares & df & Mean Square & F & \multicolumn{1}{|c|}{ Sig. } \\
\hline $1 \quad$ Regression & 266,426 & 3 & 88,809 & 195,661 & $.000^{a}$ \\
Residual & 1,794 & 37 &, 454 & & \\
Total & 283,220 & 40 & & & \\
\hline
\end{tabular}

a. Predictors: (Constant), $\mathrm{X} 3, \mathrm{X} 2, \mathrm{X} 1$

b. Dependent Variable $Y$

Sumber : Data Primer Diolah, 2015 
Sesuai tabel diatas $F_{\text {hitung }}$ adalah 195,661 dengan signifikansi 0,000 sehingga dapat diartikan bahwa kepemimpinan, motivasi, stres kerja berpengaruh signifikan secara bersamasama terhadap kinerja Karyawan CV. Dian Prima Kebumen (Ghozali, 2009: 91).

\section{Koefisien Determinasi}

Koefisien determinasi regresi yang telah dilakukan adalah:

Gambar IV.6

Koefisien Determinasi

Model Summaryb

\begin{tabular}{|l|r|r|r|r|}
\hline Model & \multicolumn{1}{|c|}{$\mathrm{R}$} & $\mathrm{R}$ Square & Adjusted R Square & Std. Error of the Estimate \\
\hline 1 & $.970^{\mathrm{a}}$ & .941 & .936 &, 67371 \\
\hline
\end{tabular}

a. Predictors: (Constant), X3, X2, X1

b. Dependent Variable: $Y$

Sumber : Data Primer Diolah, 2015

Sesuai tabel diatas, nilai koefisien determinasi sebesar 0,936 artinya 93,6\% kinerja dipengaruhi oleh kepemipinan, motivasi, stres kerja. Sebaliknya 6,4\% yang lain disebabkan oleh variabel lain yang tidak ada dalam penelitian ini.

\section{KESIMPULAN}

Penelitian ini adalah penelitian deskriptif dan kuantitatif yang yang bertujuan untuk menemukan bagaimana pengaruh faktor terkait kepemimpinan, motivasi dan stres kerja pada kinerja CV. Dian Prima Kebumen yang menghasilkan kesimpulan sebagai berikut:

1. Variabel kepemimpinan terhadap kinerja karyawan CV. Dian Prima Kebumen menunjukan pengaruh yang positif terhadap kinerja. Artinya kepemimpinan di CV. Dian Prima Kebumen memiliki kontribusi positif dan kuat pada peningkatan kinerja. Penerapan hasil penelitian ini adalah diperlukan usaha mempertahankan dan meningkatkan kepemimpinan dari manajer atau pimpinan yang mampu memperhatikan dan mengarahkan karyawan agar bekerja lebih baik, membantu bawahan menangani permasalahan, memberi dukungan, mengevaluasi dan memberi apresiasi secara adil kepada karyawan agar kinerja mereka semakin meningkat. Sesuai dengan indikator kepemimpinan dalam penelitian ini yaitu; arahan, supervisi, konsultasi dan pendeglasian wewenang.

2. Variabel motivasi terhadap kinerja juga menunjukkan nilai positif dan signifikan, artinya variable motivasi memiliki pengaruh yang kuat dan positif terhadap kinerja karyawan $\mathrm{CV}$. Dian Prima Kebumen. Karena nilainya positif maka untuk meningkatkan kinerja pegawai diperlukan motivasi selalu dipertahankan oleh setiap karyawan. Sesuai indikator motivasi yaitu mempunyai sifat agresif, kreatif dalam melaksanakan pekerjaan, mutu pekerjaan meningkat dari hari ke hari, memtuhi jam kerja, tugas yang diselesaikan dengan kemampuan, inisiatif kerja tinggi dapat mendorong kerja, kesetiaan dan kejujuran, terjalin hubungan antar karyawan dengan pimpinan, tercapai tujuan perorangan dan tujuan organisasi, menghasilkan informasi yang akurat dan tepat.

3. Variabel stres kerja menunjukkan nilai pengaruh yang negatif dan tidak signifikan terhadap kinerja karena stres dapat membantu kinerja seseorang tergantung seberapa besar tingkat stres 
itu. Bila tidak ada stres tantangan kerja juga tidak ada prestasi kerja cenderumg menurun, sejalan dengan meningkatnya stres, kinerja cenderumg naik karena stres kerja membantu karyawan mengarahkan kualitas hasil kerja karyawan dan yang menjadi indikator stres kerja ialah cepat tersinggung, tidak komunikatif, banyak melamun, lelah mental, meningkat detak jantung dan tekanan darah, mudah lelah secara fisik, pusing kepala, problem tidur, menunda atau menghindari pekerjaan.

4. Berdasarkan uji validitas menunjukkan bahwa semua variabel valid (syah). Kecuali butir ke 3 pada variabel kepemimpinan butir ke 1 pada variabel motivasi dan butir ke 5 pada stres kerja. Uji reliabilitas menunjukkan semua variabel reliabel (handal). Sedangkan berdasarkan uji asumsi klasik, semua data tidak memiliki masalah dengan multikolineritas, heterokedastisitas dan uji normalitas, sehingga model regresi dapat dipakai.

5. Hasil uji t dapat disimpulkan bahwa variable kepemimpinan, motivasi yang berpengaruh signifikan secara parsial/sendiri-sendiri terhadap kinerja karryawan CV. Dian Prima Kebumen.

6. Hasil uji $\mathrm{F}$ menunjukkan $\mathrm{F}_{\text {hitung }}$ adalah 195,661 dengan signifikansi 0,000 sehingga dapat diartikan yang positif dan signifikan terhadap kinerja, artinya secara bersama-sama variabel kepemimpinan, motivasi dan stres kerja memiliki pengaruh yang signifikan terhadap kinerja karyawan CV. Diam Prima Kebumen.

\section{DAFTAR PUSTAKA}

Arikunto, Suharsini. 2002. Prosedur Penelitian: Suatu Pendekatan Praktik. Edisi Revisi. Yogyakarta: Graha Ilmu

Arief Pramono, 2007. Program jasa dan kualiatas pelayanan, Malang: Banyumedia. Publishing. Anoraga, Pandji, 2004, Manajemen Bisnis, Cetakan Ketiga, Rineka Cipta. Jakarta.

Andreas Priyono, 2001 Petunjuk Praktis Classrom Base Action Researh. Semarang: Kanwil Depdiknas Propinsi Jawa Tengah.

Djarwanto Ps dan Pangestu Subagyo, 2009 Statistik Induktif Edisi Empat. Yogyakarta Badan Percetakan Fakultas Ekonomi Universitas Gajah Mada.

Ghozali. 2009. Aplikasi Analisis Multivariate dengan Program SPSS. Badan Penerbit Universitas Diponegoro Semarang.

Gordon, Jr. 2002. Organizational behaviour: a Diagnostic Approach, New Jersey, USA.Penerbit Prentice Hall Internasional Inc.

Handoko, Hani. 2011. Manajemen Personalia dan Sumber Daya Manusia.BPFE. Yogyakarta. Hadi, Sutrisno. 2004. Metodologi Research Jilid 3. Yogyakarta: Penerbit Andi.

Mangkunegara, Anwar Prabu. 2004. Perencanaan dan Pengembangan Sumber Daya Manusia. Bandung: Penerbit Refika Aditama.

Malayu SP Hasibuan. 2003. Manajemen Sumber Daya Manusia Edisi Revisi. Jakarta: Bumi Aksara.

Mas'ud, Fuad. 2004. Survai Diagnosis Organisasional : Konsep dan Aplikasi. Badan Peneribit UNDIP. Semarang.

Mas'ud, Fuad. 2004. Survai Diagnosis Organisasional : Konsep dan Aplikasi. Badan Peneribit UNDIP. Semarang.

Nimran, U. 1997. Perilaku Organisasi. Cetakan Pertama. CV. Citramedia. Surabaya. 
Riyadi (2011). "Pengaruh Kompensasi Finansial, Gaya Kepemimpinan, dan Motivasi Kerja Terhadap Kinerja Karyawan pada Perusahaan Manufaktur di Jawa Timur". Jurnal Manajemen dan Kewirausahaan, Vol. 13, No. 1, Maret 2011:40-45.Semarang.

Robbins Stepen, 2007, Perilaku Organisasi. Jakarta: Salemba Empat.

Sugiyono, 2012, Statistik untuk Penelitian, Alfabeta, Bandung.

Sayuti, 2006, Motivasi dan Faktor-faktor yang Mempengaruhinya, Penerbit

Ghalia Indonesia, Jakarta.

Sutrisno, Hadi. 2004. Metode Riset Jilid II. Yogyakarta: Penerbit Andi Offset.

Sekaran, Uma, 2006. Research Metodelogi penelitian untuk bisnis Edisi 4, Jakarta: Salemba Empat

Suwarso, 2006. Manajemen Ketenagakerjaan. Jakarta: Bumi Aksara. 